Egyptian Poultry Science Journal

http://www.epsaegypt.com

ISSN: 1110-5623 (Print) - 2090-0570 (Online)

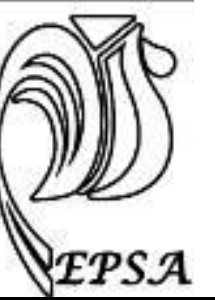

\title{
EFFECTS OF MORINGA LEAFAS A NATURAL ANTIOXIDANT ON GROWTH PERFORMANCE, BLOOD LIPID PROFILES AND IMMUNE RESPONSE OF RABBITS UNDER MODERATE HEAT STRESS
}

Yassmine M. El-Gindy; H. S. Zeweil; and M. Hamad

Dep. of Anim. and Fish Prod., Fac. of Agric. (Saba Basha), Alexandria Uni.

Corresponding author: Yassmine M. El-Gindy; E-mail: Y.M.elgindy@alexu.edu.eg

Received:19/03/2017

Accepted:05/04/2017

\begin{abstract}
Heat stress has negative effects on the performances of growing rabbits. The rabbit sector is a more vulnerable to global warming and climate change. The objective of this paper was studying effects of moringa leaf meal (MLM) on performance, immune response, and blood lipid profiles of growing rabbits under moderate heat stress. Forty-eight V-line unsexed rabbits, 5 weeks old, with initial weight of $704.4 \pm 68.19 \mathrm{~g}$ were used and allocated randomly to four groups of 12 rabbits each. Frist group fed basal diet free of feed additives (control). Second, third and fourth groups fed basal diet with $0.1,0.2$ and $0.3 \%$ MLM supplementation, respectively. The results revealed that final body weight was significantly increased by the inclusion of MLM at 0.2 and $0.3 \%$ compared with control. There was significant decrease in daily feed intake with an increase in the rate of MLM up to $0.2 \%$. Moringa significantly increased antibody titters against SRBCs compared with control group at 7,14 and 21 days after vaccination. Also, it stimulated significantly IgM immune response of growing rabbits in comparison with the control group. Serum cholesterol, LDL and MDA levels were significantly decreased as MLM concentration administered increases. Significant increase in total antioxidant capacity was recorded due to MLM supplementation in comparison with control. Based on the experimental results, it is concluded that supplementing rabbits under moderate heat stress with MLM could be better strategy to improve immune response and blood lipid profiles.
\end{abstract}

Key words: Rabbits - Moringa - Antioxidant status - Hematological parameter. 


\section{INTRODUCTION}

Global warming has a great impact on the productive status of rabbits. It has risen the earth surface temperature by about $0.7^{\circ} \mathrm{C}$ since the early $20^{\text {th }}$ century. It is expected that the global temperature rise will reach $1.8-4^{\circ} \mathrm{C}$ by 2100 (IPCC, 2014). Also, Heat stress can cost rabbit farmers a significant amount of money, due to production losses in meat rabbit production (Villalobos et al., 2008).

Heat stress raises lipid oxidation as a result of increasing free radical generation which increases the formation of reactive oxygen species and induces oxidative stress(Altan et al., 2003). On the other hand, Moringa Oleifera is one of the plants that contain natural antioxidants such as zeatin, kaempferol, caffeoylquinic acid, quercetin and $\beta$ - sitosterol, which act as antioxidant, antimalarial, cardiac stimulant and has antibacterial and antifungal activities (Farooq et al., 2007). Additionally, the antioxidant properties of moringa leaves can be due to the existence of glycosides, tannins, anthocyanin, polyphenols and thiocarbamates, which activate antioxidant enzymes, inhibit oxidasesand eliminate free radicals, (Luqmans et al., 2012). Therefore, the aim of this study was to examine the effect of various supplementation of MLM as a natural source of antioxidant on growth performance, immune response and blood lipid profiles of growing $\mathrm{V}$-line rabbits under moderate heat stress.

MATERIALS AND METHODS Animal and their management

Forty-eight growing V-line unsexed rabbits, 5 weeks old, with initial weight of $704.4 \pm 68.19 \mathrm{~g}$ were randomly disturbed to four treatments $(n=12)$. Each treatment was sub-divided into 4 replicate $(n=3)$. Rabbits were kept in wire batteries of $45 \times 36 \times 36 \mathrm{~cm}$ under hygienic conditions and were fed experimental dietsad libitum until 12 weeks of age. Four pelleted diets were prepared. The first group was fed basal diet free of feed additives (control). Second, third and fourth groups were fed basal diet with 0.1 ,
0.2 and $0.3 \%$ MLM supplementation, respectively. Fresh water was automatically available at all times for each cage. The ingredients of the experimental diets areshow in Table (1) covered the nutrition requirements according to NRC (1977).

\section{Moringa preparation}

The moringa leaves were collected from a private farm of sandy soil in Borg El-Arab city, Alexandria, Egypt. The harvested leaves were air dried in shade under a shed until they were crispy to touch while retaining their greenish coloration. The dried leaves were then milled using a hammer mill (1 mm mesh) to produce MLM suitable for incorporation into rabbit's diets.

\section{Environmental data and heat tolerance measurements}

Air temperature and humidity were recorded daily by room thermometer and hygrometer. Temperature-humidity index $(\mathrm{THI})=\mathrm{db} \cdot \mathrm{C}$ - [(0.31-0.31 RH \%) $\left.\left(\mathrm{db}{ }^{\circ} \mathrm{C}-14.4\right)\right]$, whereas $\mathrm{db}^{\circ} \mathrm{C}=$ dry bulb temperature in Celsius and $\mathrm{RH}=$ relative humidity \% (Marai et al., 2001). The THI values were classified as: $<27.8=$ absence of heat stress; 27.8 to $<28.9=$ moderate heat-stress, 28.9 to $<30.0=$ severe heat stress and $>30.0$ over severe heat stress. Respiration rate per minute (RpM) was measured by counting the flank movement per minute and rectal temperature $\left({ }^{\circ} \mathrm{C}\right)$ was measured by clinical thermometerat mid-day (between 12 am to 3 $\mathrm{pm})$ on $3^{\text {rd }}$ and $6^{\text {th }}$ week of the experiment.

\section{Data collect}

Rabbits have never been treated with any kind of systematic vaccination or medication. Live body weight and feed intake were recorded weekly. Also, daily weight gain and feed conversion were calculated. At the end of the feeding trial, 6 $\mathrm{ml}$ of blood sample was taken from 6 rabbit's ear veins of each treatment with a sterile syringe. $2 \mathrm{ml}$ of the blood was put into a bijou bottle containing ethylene diaminetetraacetic acid (EDTA) for hematological assay. The remaining $4 \mathrm{ml}$ of the blood sample was put into a sterile vacutainer tube without an anticoagulant for 
Rabbits - Moringa - Antioxidant status - Hematological parameter.

serum biochemical analysis. The hematological assay was carried out to determine haemoglobin $(\mathrm{Hb})$ values, red blood cell (RBC) counts according to Natt and Herrick (1952), packed cell volume (PCV) and white blood cell (WBC) according to Hepler (1966). The differential count of specific types of leukocytes was according to the Pappenheim method. Serum total lipids, triglycerides, cholesterol, LDL and high-density lipoprotein (HDL), Aspartate aminotransferas (AST), Alanine aminotransferase (ALT), total antioxidant capacity (TAC) and MAD concentrations were estimated using commercial kits (Bio Merieux, France). Serum immunoglobulin $\mathrm{IgG}$ and IgM were determined using ELISA technique. Four rabbits of each group were immunized with $0.1 \mathrm{ml}$ of a $2.5 \%$ Sheep Red Blood Cells (SRBCs) at 15 days after starting the experimental diets, to measure Antibody titer against SRBCs. Antiserum to SRBCs was collected 7, 14 and 21 days post-challenge according to Wegmann and Smithies (1966). The agglutination titer was expressed as the $\log ^{2}$ (Nelson et al., 1995).

\section{Statistical analysis}

Results were expressed in the mean \pm SD. All data were analyzed using one-way analysis of variance (ANOVA) using SPSS 11.0 statistical software (SPSS, Inc., Chicago, Il, 2001). Significant differences between means were detected using new Duncan multiple range tests (Duncan, 1955).

RESULTS AND DISCUSSIONS Meteorological parameters and heat tolerance measurements

Considering the overall mean of THI for the experimental period it is clear that rabbits were exposed to moderate heatstress, whereas ambient temperature ranged between (28.0-31.2 ${ }^{\circ} \mathrm{C}$ ); THI 28.1 and relative humidity was (63.3-74.8\%). Generally, body temperature is affected by many factors such as feed, environmental temperature, disease, sex and age (Guyton and Hall, 2000). The results revealed nonsignificant effect on respiration rate and rectal temperature (at $3^{\text {rd }}$ and $6^{\text {th }}$ week) due to different treatments as compared with control (Fig. 1A\&B).

\section{Growth performance}

At 12 weeks of age, (Table 3) the final live body weight has increased significantly by the inclusion of MLM at $0.2 ; 0.3 \%$ in comparison with control group. There was significant decrease in daily feed intake with an increase of MLM up to $0.2 \%$. The observed results showing that inclusion of MLM improve the feed conversion ratio in comparison with the control group, but this improvement didn't reach significant level.

The positive effect of MLM on growth performance of rabbits was noticed in some previous studies, Nuhu (2010), regarded the better growth rate to protein quality and amino acids content of moringa leaves. ElBadawi et al. (2014) suggested that moringa dry leaves at level $(0.15$ or $0.30 \%)$ could use as a natural growth promoter. In the same time, certain adverse effect could be due to the high content of some phytochemical compounds (phenols, coumarins, alkaloids and tannins), or might be due to the fact that M. oleifera is rich in amino acids, vitamins and minerals particularly iron (Faye et al., 2011).

\section{Hematological parameters}

Results in Table 4 show that hemoglobin was not significantly affected by different levels of MLM. Results show a significant increase in WBCs values in the group fed diets containing MLM supplementation in comparison with control. Data show that PCV\% was significantly increased with the addition of MLM that may due to numerical increase in RBCs count and significantly increased in WBCs. The increase in the values of $\mathrm{PCV}$ indicates a more proper nutrient absorption within the system of the animal. High counts of WBCs enhance adaptability to local environment and disease prevalent conditions (Soetan et al., 2013). The percentage of lymphocytes was significantly decreased, while neutrophils was increased but results were in the normal range. 


\section{Immune responses}

Results (Fig. 2) indicate that MLM significantly increased antibody titters against SRBCs compared with control group at 7, 14 and 21 days after vaccination. Primary and secondary humoral immune response, the level of specific IgM and IgG, together with the intensity of delayed-type hypersensitivity to sheep erythrocytes were investigated in rabbits fed with MLM load for a month. It is shown that MLM was immunomodulatory. It stimulated numerically $\operatorname{IgG}$ and significantly $\operatorname{IgM}$ immune response of growing rabbits (Table 4) in comparison with the control group. Our results get along with Olugbemi et al. (2010) who demonstrated that moringa leaves have a beneficial effect on the immune responses and improve intestinal health of broilers. Also, Sudha et al. (2010) showed that moringa leaves methanol extract givenorally to mice at doses of 250 and $750 \mathrm{mg} / \mathrm{kg}$ stimulated both cellular and humoral immune responses.

Biochemical constituents of blood serum

Results illustrated in Table 4 show that serum cholesterol and LDL levels were significantly reduced as the concentration of MLM meal administered increases. Lowdensity lipoprotein is a major component of the total cholesterol and is directly related to coronary heart disease as a major atherogenic lipoprotein and hence, appears to be the main target of any lipid lowering agent, such as the moringa leaves, as reflected in our study. Farooq and Rashid (2007) demonstrated that moringa oil from a wild provenance contained phytosterols among which are campesterol, stigmasterol, and $\beta$-sitosterol. $\beta$-sitosterol which is plant sterol with a structure similar to that of cholesterol, except for the substitution of an ethyl group at $\mathrm{C} 24$ of its side chain. It could lower cholesterol by lowering plasma concentrations of LDL. This bioactive component of moringa (sitosterol, a bioactive phytoconstituent) may in part be responsible for the hypocholesterolemic effect (Mbikay, 2012). Also, the hypolipidemia of MLM may be due two mechanism actions: HMG-Co-A reductase catalyzes rate limiting process of cholesterol biosynthesis and reduced the absorption of dietary cholesterol and liver cholesterol by biliary secretion (Hassarajani et al., 2007).

Results show (Table 4) a significant improved in serum total antioxidant capacity and malondialdehyde in rabbits fed diets containing MLM in comparison with control. Recently, Lamou et al. (2016) reported that aqueous extract of moringa $(100,200$, or $400 \mathrm{mg} / \mathrm{kg})$ increased the activity of antioxidant enzymes and decreased the blood concentrations of MAD in rats subjected to forced swimming endurance test.

Result present in Table 4 reveals that serum biochemical indices AST and ALT were not significantly affected, whereas indicating that the treatments have no untoward effect on the health status of the rabbits. These results were in agreement with Ewuola et al. (2015) who showed that unchanged levels of ALT and AST in the serum were an indication of no obvious damage to muscle and organs such as the liver and kidney of rabbits. This result disagree with Adedapo et al. (2009) who found that 400 and 600 $\mathrm{mg} / \mathrm{kg}$ doses of moringa leaf extract showed a significant increase in the levels of liver enzymes as ALT and AST. 
Table (1): Composition and chemical analysis of moringa and tested diets

\begin{tabular}{|c|c|c|c|c|c|}
\hline \multirow{2}{*}{ Ingredients } & \multicolumn{5}{|c|}{ Treatments } \\
\hline & Control & MLM 0.1\% & \multicolumn{2}{|c|}{ MLM 0.2\% } & MLM 0.3\% \\
\hline Corn yellow & 19.0 & 18.9 & \multicolumn{2}{|c|}{18.8} & 18.7 \\
\hline Wheat bran & 11.0 & 11.0 & \multicolumn{2}{|c|}{11.0} & 11.0 \\
\hline Barley & 17.2 & 17.2 & \multicolumn{2}{|c|}{17.2} & 17.2 \\
\hline Berseem hay & 33.0 & 33.0 & \multicolumn{2}{|c|}{33.0} & 33.0 \\
\hline Soybean meal $44 \%$ & 15.0 & 15.0 & \multicolumn{2}{|c|}{15.0} & 15.0 \\
\hline Molasses & 3.0 & 3.0 & \multicolumn{2}{|c|}{3.0} & 3.0 \\
\hline Di-Calcium phosphate & 1.0 & 1.0 & \multicolumn{2}{|c|}{1.0} & 1.0 \\
\hline Lysine & 0.1 & 0.1 & \multicolumn{2}{|c|}{0.1} & 0.1 \\
\hline Methionine & 0.1 & 0.1 & \multicolumn{2}{|c|}{0.1} & 0.1 \\
\hline Vitamins premix & 0.3 & 0.3 & \multicolumn{2}{|c|}{0.3} & 0.3 \\
\hline $\mathrm{Nacl}$ & 0.3 & 0.3 & \multicolumn{2}{|c|}{0.3} & 0.3 \\
\hline Moringa & - & 0.1 & \multicolumn{2}{|c|}{0.2} & 0.3 \\
\hline Total & 100 & 100 & \multicolumn{2}{|c|}{100} & 100 \\
\hline \multicolumn{6}{|c|}{ Chemical analysis determined (DM\% basis) } \\
\hline & Dried & & Tres & & \\
\hline Chemical analysis\% & Moringa & & & MIM & \\
\hline & & Contror & $0.1 \%$ & $0.2 \%$ & $0.3 \%$ \\
\hline Organic matter & 91.58 & 91.75 & 91.75 & 91.85 & 91.9 \\
\hline Crude protein & 31.62 & 16.9 & 17.31 & 17.40 & 17.55 \\
\hline Crude fiber & 9.35 & 13.43 & 13.25 & 13.27 & 13.29 \\
\hline Ether Extract & 8.42 & 2.86 & 2.95 & 2.97 & 2.99 \\
\hline $\mathrm{NFE}^{*}$ & 42.22 & 58.56 & 58.24 & 58.21 & 58.07 \\
\hline $\mathrm{NDF} \uparrow$ & 35.07 & 37.75 & 37.63 & 37.64 & 37.66 \\
\hline
\end{tabular}

$*$ Nitrogen free extract $(\mathrm{NFE})=($ Organic matter $)-($ Crude protein + Crude fiber + Ether Extract $)$. $\dagger$ Neutral Detergent Fiber $(\mathrm{NDF})=28.924+0.657 \times \mathrm{CF} \%$. 
Table (2): Overall means of air temperature (AT), relative humidity (RH) and temperature-humidity index (THI).

\begin{tabular}{|l|l|l|l|l|l|l|l|}
\hline & \multicolumn{3}{|c|}{ AT[ $\left.{ }^{\circ} \mathbf{C}\right]$} & \multicolumn{3}{c|}{ RH\% } & THI \\
\cline { 2 - 8 } & Maxi. & Min. & Aver. & Max. & Min. & Aver. & \\
\hline 1- 3 week & 29.1 & 26.4 & 27.8 & 62.4 & 72.7 & 67.6 & 26.4 \\
3- 6 week & 33.3 & 29.6 & 31.5 & 64.2 & 76.8 & 70.5 & 29.9 \\
Overall mean & 31.2 & 28.0 & 29.6 & 63.3 & 74.8 & 69.0 & 28.1 \\
\hline
\end{tabular}

Table (3): Effect of MLM on rabbit's growth performance from 5 to 12 weeks of age (mean \pm SD)

\begin{tabular}{|l|l|l|l|l|l|}
\hline \multirow{2}{*}{ Characteristics } & Control & \multicolumn{3}{|c|}{ MLM \% } & \multicolumn{1}{|c|}{$\mathbf{0 . 3}$} \\
\cline { 2 - 6 } & & \multicolumn{1}{|c|}{$\mathbf{0 . 1}$} & \multicolumn{1}{c|}{ Pvalue } \\
\hline Initial body weight, g & $705.00 \pm 66.89$ & $700.00 \pm 69.25$ & $705.83 \pm 67.41$ & $706.67 \pm 69.21$ & 0.995 \\
Final body weight, g & $1960.00^{\mathrm{b}} \pm 125.19$ & $2006.33^{\mathrm{ab}} \pm 71.50$ & $2047.50^{\mathrm{a}} \pm 68.14$ & $2048.75^{\mathrm{a}} \pm 59.65$ & 0.044 \\
Daily weight gain, g & $26.00 \pm 1.82$ & $26.25 \pm 2.06$ & $28.00 \pm 1.42$ & $28.00 \pm 1.72$ & 0.234 \\
Daily feed intake, g & $68.42^{\mathrm{ab}} \pm 1.42$ & $67.24^{\mathrm{bc}} \pm 0.72$ & $65.81^{\mathrm{c}} \pm 0.36$ & $69.68^{\mathrm{a}} \pm 1.7$ & 0.004 \\
Feed conversion ratio & $2.64 \pm 0.16$ & $2.57 \pm 0.18$ & $2.36 \pm 0.12$ & $2.49 \pm 0.14$ & 0.109 \\
\hline
\end{tabular}

Different letters (a-c) within a raw denote significant differences between treatments $(\mathrm{p} \leq 0.05)$ 
Rabbits - Moringa - Antioxidant status - Hematological parameter.

Table (4): Effect of MLM on hematological parameters, serum lipid profile, antioxidant status and liver function of growing rabbits (mean \pm SD)

\begin{tabular}{|c|c|c|c|c|c|}
\hline \multirow[t]{2}{*}{ Characteristics } & \multirow{2}{*}{ Control } & \multicolumn{3}{|c|}{ MLM \% } & \multirow{2}{*}{$\begin{array}{c}\mathbf{P} \\
\text { value }\end{array}$} \\
\hline & & 0.1 & 0.2 & 0.3 & \\
\hline \multicolumn{6}{|l|}{ Hematology: } \\
\hline RBCs* $* 10^{6}$ & $2.97 \pm 0.20$ & $3.08 \pm 0.24$ & $3.16 \pm 0.20$ & $3.27 \pm 0.15$ & 0.09 \\
\hline WBCs $* 10^{3}$ & $5.47^{c} \pm 0.59$ & $6.17^{\mathrm{b}} \pm 0.37$ & $6.42^{\mathrm{ab}} \pm 0.49$ & $6.81^{\mathrm{a}} \pm 0.49$ & 0.001 \\
\hline Hemoglobin, $\mathrm{mg} / \mathrm{dl}$ & $11.72 \pm 0.29$ & $11.83 \pm 0.20$ & $11.88 \pm 0.22$ & $11.85 \pm 0.27$ & 0.70 \\
\hline $\mathrm{PCV} \%$ & $38.25^{\mathrm{b}} \pm 1.22$ & $39.85^{\mathrm{a}} \pm 0.71$ & $39.38^{\mathrm{a}} \pm 0.66$ & $39.48^{\mathrm{a}} \pm 0.54$ & 0.01 \\
\hline Eosinophil \% & $1.47 \pm 0.27$ & $1.52 \pm 0.20$ & $1.73 \pm 0.17$ & $1.58 \pm 0.22$ & 0.21 \\
\hline Neutrophils \% & $35.28^{\mathrm{c}} \pm 1.22$ & $41.60^{b} \pm 2.69$ & $42.57^{\mathrm{ab}} \pm 1.35$ & $44.05^{\mathrm{a}} \pm 1.22$ & 0.001 \\
\hline Lymphocytes \% & $60.57^{\mathrm{a}} \pm 1.37$ & $54.40^{\mathrm{b}} \pm 2.62$ & $53.32^{b c} \pm 1.22$ & $51.92^{c} \pm 1.35$ & 0.001 \\
\hline Monocytes \% & $2.68 \pm 0.39$ & $2.48 \pm 0.31$ & $2.38 \pm 0.12$ & $2.45 \pm 0.17$ & 0.22 \\
\hline \multicolumn{6}{|l|}{ Immunity traits: } \\
\hline $\mathrm{IgG}, \mathrm{mg} / \mathrm{dl}$ & $211.62 \pm 11.39$ & $227.50 \pm 19.37$ & $226.33 \pm 26.06$ & $224.67 \pm 21.36$ & 0.522 \\
\hline $\mathrm{IgM}, \mathrm{mg} / \mathrm{dl}$ & $16.94^{c} \pm 0.22$ & $17.15^{b c} \pm 0.29$ & $17.61^{\mathrm{ab}} \pm 0.37$ & $17.78^{\mathrm{a}} \pm 0.59$ & 0.004 \\
\hline \multicolumn{6}{|l|}{\begin{tabular}{|l|} 
Lipid profile: \\
\end{tabular}} \\
\hline Total lipids, mg/dl & $174.00 \pm 11.83$ & $174.83 \pm 13.84$ & $177.33 \pm 14.65$ & $177.33 \pm 9.50$ & 0.952 \\
\hline Triglycerides, mg/dl & $57.49 \pm 3.33$ & $58.95 \pm 1.91$ & $59.53 \pm 1.03$ & $59.63 \pm 0.44$ & 0.258 \\
\hline Total cholesterol, $\mathrm{mg} / \mathrm{dl}$ & $100.89^{\mathrm{a}} \pm 4.92$ & $97.57^{\mathrm{ab}} \pm 2.18$ & $96.17^{\mathrm{b}} \pm 3.65$ & $93.15^{\mathrm{b}} \pm 2.87$ & 0.01 \\
\hline $\mathrm{HDL}^{*} \mathrm{mg} / \mathrm{dl}$ & $52.29 \pm 2.19$ & $53.60 \pm 1.40$ & $54.59 \pm 1.52$ & $54.86 \pm 2.16$ & 0.098 \\
\hline $\mathrm{LDL}^{*} \mathrm{mg} / \mathrm{dl}$ & $48.61^{\mathrm{a}} \pm 5.04$ & $43.96^{\mathrm{b}} \pm 1.78$ & $41.58^{b c} \pm 4.41$ & $38.29^{c} \pm 3.09$ & 0.001 \\
\hline \multicolumn{6}{|l|}{ Antioxidant status: } \\
\hline $\mathrm{TAC}^{\dagger} \mathrm{mmol} / \mathrm{l}$ & $1.44^{\mathrm{b}} \pm 0.15$ & $2.11^{\mathrm{a}} \pm 0.28$ & $2.15^{\mathrm{a}} \pm 0.20$ & $2.28^{\mathrm{a}} \pm 0.29$ & 0.006 \\
\hline $\mathrm{MAD}^{\dagger} \mathrm{nmol} / \mathrm{ml}$ & $13.80^{\mathrm{a}} \pm 0.47$ & $11.47^{\mathrm{b}} \pm 0.61$ & $11.03^{b c} \pm 0.47$ & $10.44^{\mathrm{c}} \pm 0.64$ & 0.009 \\
\hline \multicolumn{6}{|l|}{ Liver functions } \\
\hline $\mathrm{AST}^{\ddagger} \mathrm{U} / \mathrm{L}$ & $30.16 \pm 2.82$ & $30.20 \pm 1.13$ & $30.02 \pm 0.76$ & $30.13 \pm 1.13$ & 0.998 \\
\hline $\mathrm{ALT}^{+} \mathrm{U} / \mathrm{L}$ & $17.87 \pm 1.00$ & $18.52 \pm 0.69$ & $18.37 \pm 0.54$ & $18.59 \pm 0.44$ & 0.302 \\
\hline
\end{tabular}

Different letters (a-c) within a raw denote significant differences between treatments $(\mathrm{p} \leq 0.05)$.

"HDL=High density lipoprotein; LDL=Low density lipoprotein.

TAC=Total antioxidant capacity; MAD=Malondialdehyde.

AST =Aspartate aminotransferase; ALT =Alanine aminotransferase 
Yassmine M. El-Gindy et al.
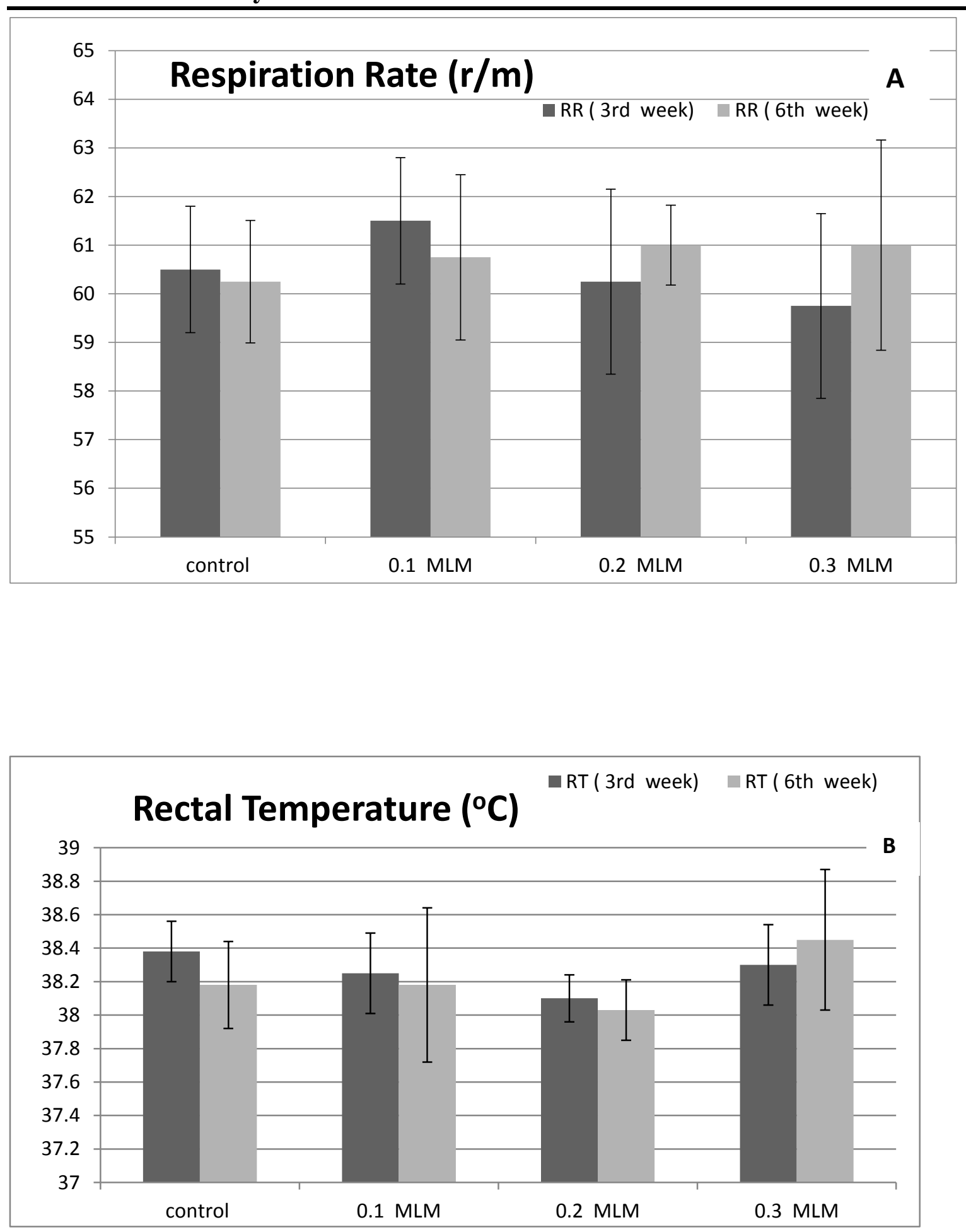

Fig.(1): Effect of MLM on rabbit's (A) respiration rate and (B) rectal temperature during $3^{\text {rd }}$ and $6^{\text {th }}$ week of experiment (mean \pm SD) 
Rabbits - Moringa - Antioxidant status - Hematological parameter.

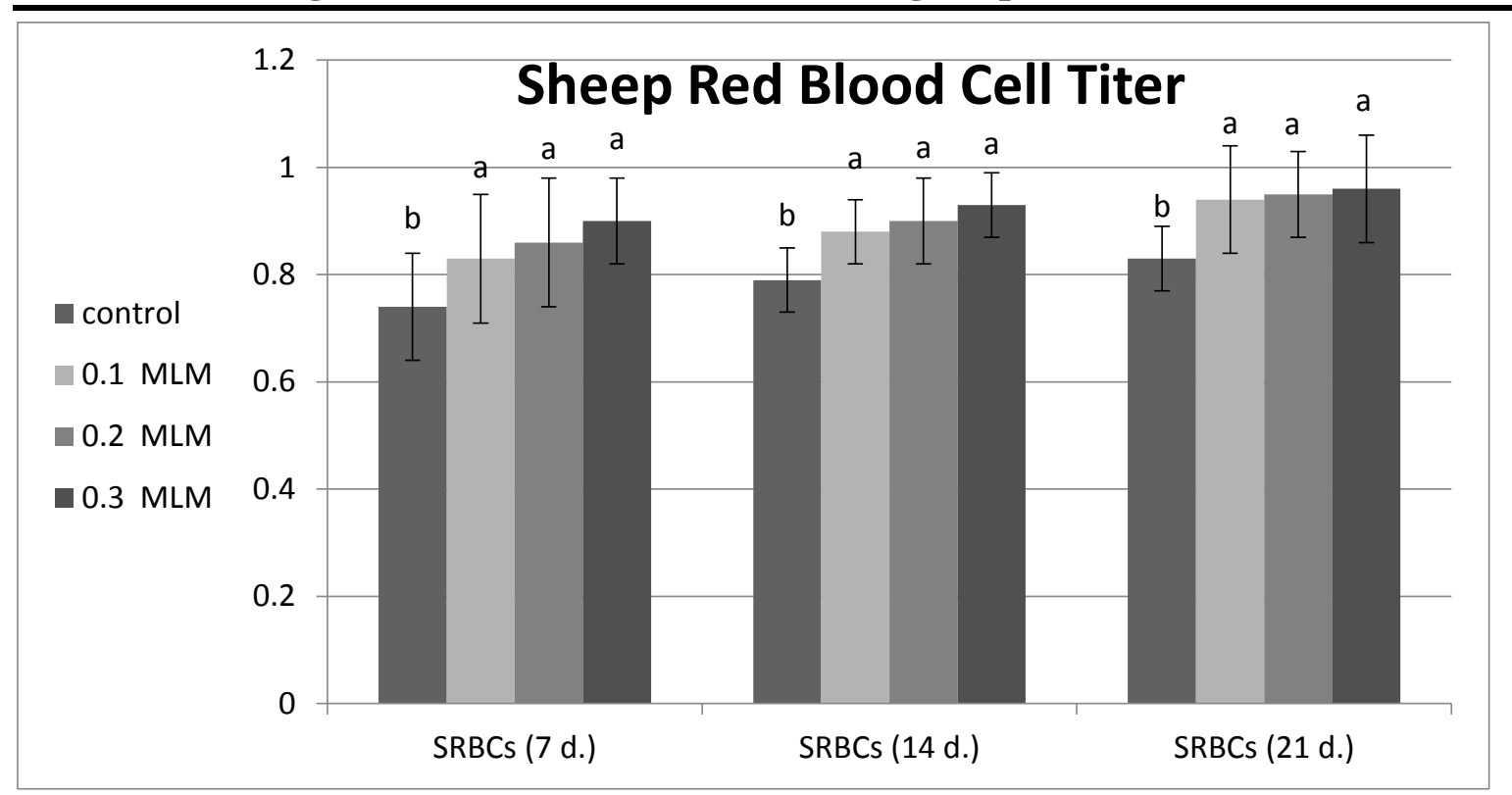

Fig.(2): Effect of MLM on rabbit's responses against sheep red blood cell post 7, 14 and 21 day of vaccination $($ mean \pm SD) 


\section{REFERENCES}

Adedapo, A. A.; Mogbojuri, O. M.; and Emikpe, B. O., 2009. Safety evaluations of the aqueous extract of the leaves of Moringaoleifera in rats. J. Med. Plants Res., 3(8): 586-591.

Altan, O.; Pabuccuoglu, A.; Altan, A.; Konyalioglu, S.; and Bayraktar, H., 2003. Effect of heat stress on oxidative stress, lipid peroxidation and some stress parameters in broilers. Br. Poult. Sci., 44: 545-550.

Duncan, D. B., 1955. Multiple ranges and multiple f-test, Biometries, 11: 1-42.

El-Badawi, A. Y.; Omer, H. A. A.; Abedo, A. A.; and Yacout, M. H. M., 2014. Response of growing New Zealand White rabbits to rations supplemented with different levels of Moringa oleifera dry leaves. Global Vet., 12(4): 573-582.

Ewuola, E. O.; Sokunbi, O. A.; Sanni, K. M.; Oyedemi, O. M.; and Lawal, T. T., 2015. Haematological and serum biochemical responses of rabbit does to crude Moringaoleifera leaf extract at gestation and lactation. Trop. Anim. Health Prod., 47: 637-642.

Farooq, A.; Sajid, L.; Muhammad, A.; and Anwarul-Hassan G., 2007. Moringa Oleifera: a food plant with multiple medicinal uses. Phototherapy Res., 21: 17-25.

Farooq, A.; and Rashid, U., 2007. Physico-chemical characteristics of Moringa oleifera seeds and seed oil from a wild provenance of Pakistan. Pakistan J. Botany, 39(5): 1443-1453.

Faye, B.; Bucheton, B.; and Banuls, A. L., 2011. Prevalence of leishmanialinfantum in a rural area of Senegal: analysis of risk factors involved in transmission to humans. Journal Transactions of the Royal Society of Tropical Medicine and Hygiene, 105: 333-340.

Guyton, A. C.; and Hall, J. E., 2000. Textbook of medical physiology. $12^{\text {th }}$ Edn., Philadelphia. Saunders Company.
Hassarajani, S.; Souza, T. D.; Mengi, S. A.; and Chattopadhayay, 2007. Efficacy study of the bioactive fraction (F-3) of Acoruscalamus in hyperlipidemia. Indian J. Pharmacol., 39: 196-200.

Hepler, O. E., 1966. Manual of Clinical Laboratory Methods. Thomas Spring Field. Illinois.

IPCC, (Intergovernmental Panel on Climate Change) 2014. Climate Change: Synthesis Report; Summary for Policymakers. Available from: https://www.ipcc. ch/pdf/ assessmentreport/ar5/syr/AR5_SYR_FINAL_SPM. pdf. Last accessed on 25-12-2015

Lamou, B.; Taiwe, G. S.; Hamadou, A.; Houlray, A. J.; Atour, M. M.; and Tan, P. V., 2016. Antioxidant and Antifatigue Properties of the Aqueous Extract of Moringa oleifera in Rats Subjected to Forced Swimming Endurance Test. Oxidative Medicine and Cellular Longevity, Article ID 3517824, 9 pages.

Luqmans, S.; Srivastava, S.; Kumar, R.; Maurya, A. K.; and Chanda, D., 2012. Experimental assessment of moringa oleifera leaf and fruit for its antistress, antioxidant, and scavenging potential using in vitro and in vivo assays. Evidence-Based Complementary and Alternative Medicine, Article ID 519084, 12 pages

Marai, I. F. M.; Ayyat, M. S.; and Abd ElMonem, U. M., 2001. Growth performance and reproductive traits at first parity of New Zealand White female rabbits as affected by heat stress and its alleviation under Egyptian conditions. J. Trop. Anim. Health Prod., 33: 1-12.

Mbikay, M., 2012. Therapeutic potential of Moringa oleifera leaves in chronic hyperglycemia and dyslipidemia: A review. Frontier Phamacol., 3(24): 1-12.

NRC, National Research Council, 1977. Nutrient Requirements of Domestic Animals. USA National Academy of Science. Washington, D. C. 
Natt, M. P.; and Herrick, C. A., 1952. A new blood diluent for counting erythrocytes and leucocytes of the chicken. Poult. Sci., 31: 735-738.

Nelson, N. A.; Lakshmanan, N.; and Lamont, S. J., 1995. Sheep red blood cell and Brucellaabortus antibody responses in chickens selected for multitraitimmunocompetence. Poult. Sci., 74: 1603-1609.

Nuhu, F., 2010. Effect of moringa leaf meal (MOLM) on nutrient digestibility, growth, carcass and blood indices of weaner rabbits. M. Sc. Thesis in Animal Nutrition, Kwame Nkrumah University of Science and Technology, Kumasi

Olugbemi, T. S.; Mutayoba, S. K.; and Lekule, F. P., 2010. Effect of Moringa (Moringa oleifera) inclusion in cassavabased diets fed to broiler chickens. Int. J. Poult. Sci., 9: 363-367.

Soetan, K. O.; Akinrinde, A. S.; and Ajibade, T. O., 2013. Preliminary studies on the haematological parameters of cockerels fed raw and processed guinea corn (Sorghum bicolor). Proceedings of $38^{\text {th }}$ Annual Conference of Nigerian Society for Animal Production, pp: 49-52.
SPSS, Statistical Packages for the Social Sciences, 2001. Statistical software for windows version 11.0 Microsoft. SPSS ®, Chicago, IL, USA.

Sudha, P.; Asdaq, S. M.; Dhamingi, S. S.; and Chandrakala, G. K., 2010. Immunomodulatory activity of methanolic leextract of Moringa oleifera in animals. Ind. J. Physiol. Pharmacol., 54: 133-140.

Villalobos, O.; Guillen, O.; and Garcia, J., 2008. Effect of cage density on growth and carcass performance of fattening rabbits under tropical heat stress conditions. World Rabbit Sci., 16: 89-97.

Wegmann, T. G.; and Smithies, O., 1966. A simple hemagglutination system requiring small amount of red cells and antibodies. Transfusion, 6: 67-73. 


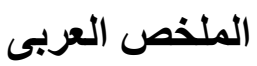

تأثير أوراق المورينجا كمضاد طبيعي للأكسدة على الأداء الإنتاجي، دهون الدم والإستجابة المناعية

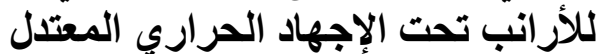

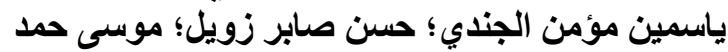

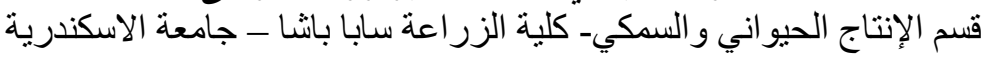

تهدف الدر اسة إلى بحث تأثير مستويات مختلفة من مسحوق أور اق المورينجا على الأداء الإنتاجي و الإاستجابة المناعية،

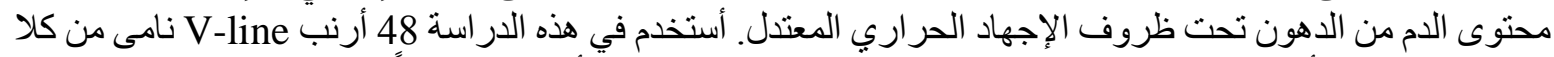

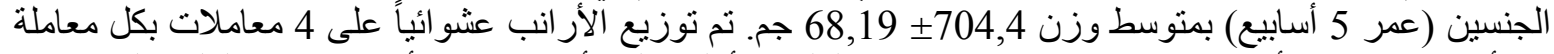

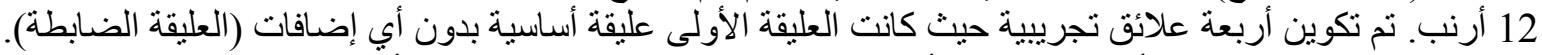

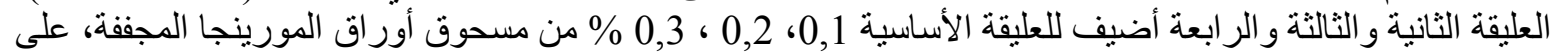

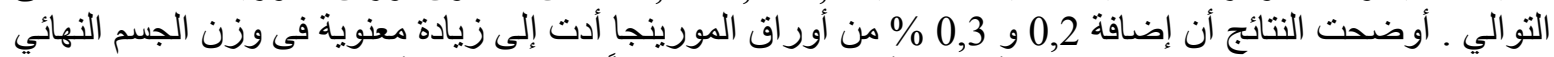

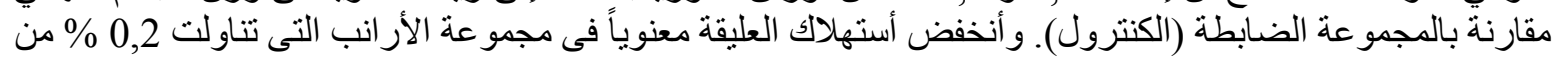

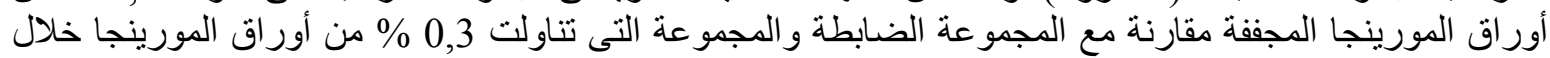

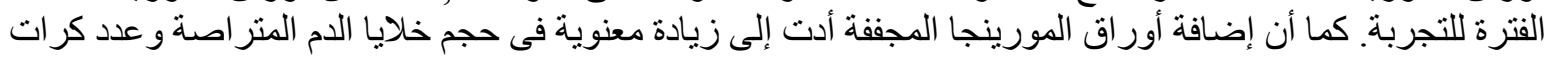

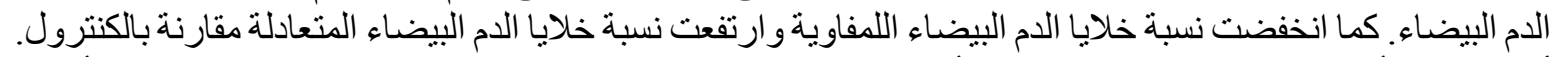

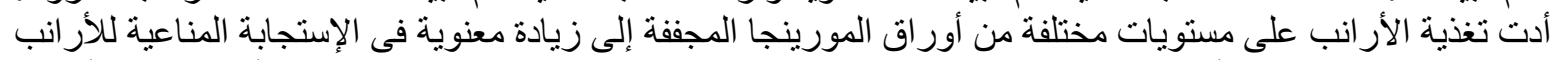

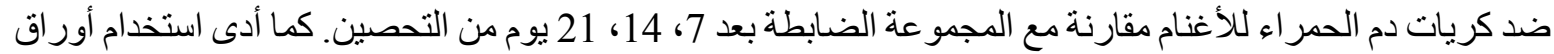

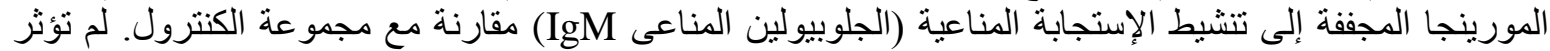

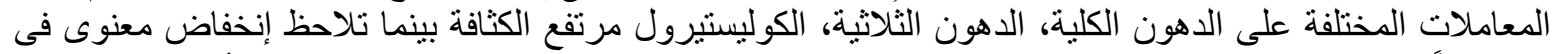

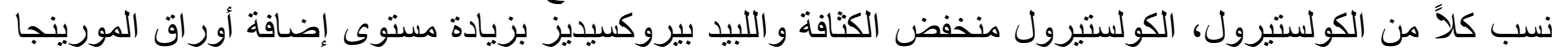

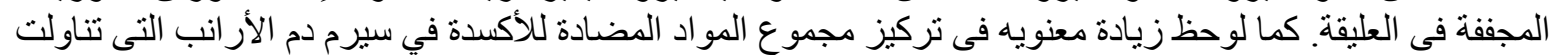

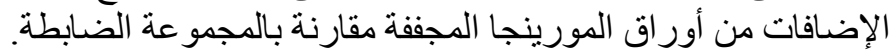

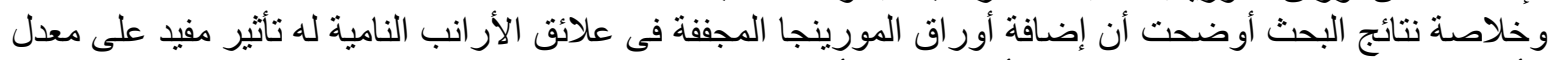

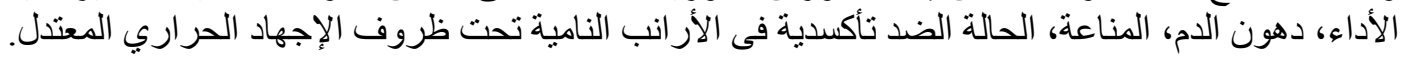

